NOTE

\title{
Multiple dermal lipomas in farmed striped seabream Lithognathus mormyrus on the Spanish Mediterranean coast
}

\author{
Serafín Gómez* \\ Histología y Anatomía Patológica, Facultad de Veterinaria, Universidad de Murcia, 30100 Murcia, Spain
}

\begin{abstract}
Two cases of multiple dermal lipomas were found in cultured striped seabream Lithognathus mormyrus (L.) from the southeast coast of Spain. A histopathological study suggests that pigmented cells may correspond to melanomacrophage aggregates. The presence of these aggregations is likely related to the occurrence of a pathological process of tumoral nature.
\end{abstract}

KEY WORDS: Fish $\cdot$ Lipoma $\cdot$ Lithognathus mormyrus

Resale or republication not permitted without written consent of the publisher

\section{INTRODUCTION}

Lipoma is a benign tumour of well-differentiated adipocytes that is found in most domestic animals (Goldschmidt \& Hendrick 2002) as well as in humans. This mesenchymal neoplasm has been reported in both freshwater and marine fish, including channel catfish Ictalurus punctatus (McCoy et al. 1985), striped grey mullet Mugil cephalus (Easa et al. 1989), southern bluefin tuna Thunnus maccoyii (Johnston et al. 2008), and northern bluefin tuna T. thynnus (Marino et al. 2006) among others.

The aim of this paper is to report the macroscopic and microscopic morphological features in 2 cases of multiple dermal lipomas in cultured striped seabream Lithognathus mormyrus from the southeastern coast of Spain.

\section{MATERIALS AND METHODS}

Two wild-caught sea bream Lithognathus mormyrus were subsequently reared under intensive culture conditions in a marine aquaculture facility in Murcia (Spain). These fish presented multiple cutaneous growths of variable size located on the trunk (Fig. 1) Both of them were found among unaffected individuals reared in the same tank. The cutaneous growths were found accidentally on both individuals at the same time. Representative tissues for histopathological study were fixed in neutral buffered formalin, embedded in paraffin, sectioned and stained with haematoxylin-

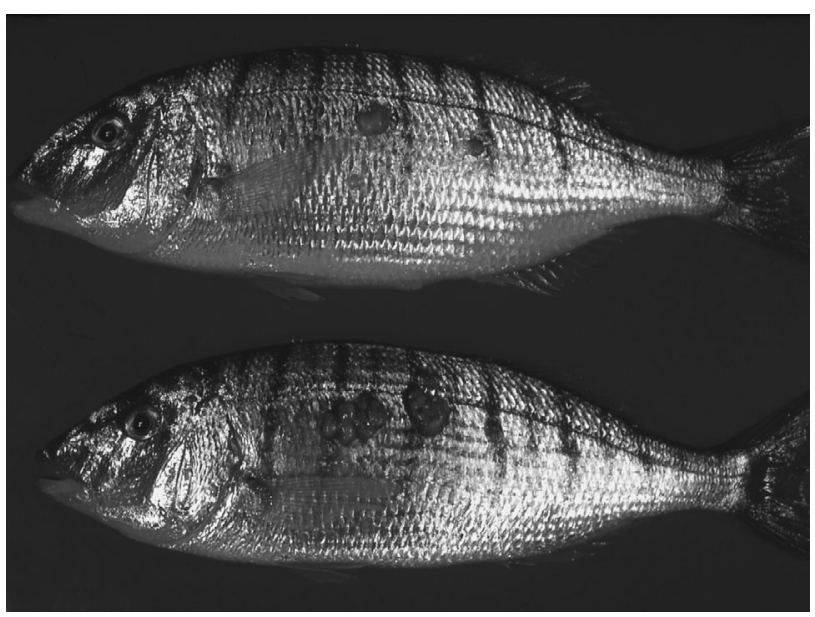

Fig. 1. Lithognathus mormyrus. Macroscopic appearance of multiple lipomas on the trunk 
eosin (HE). Further sections were also stained with Kinyoun's carbol fucsin method for lipofuscin to assess the presence of melanomacrophages, and unstained and HE sections were also examined using fluorescence microscopy.

\section{RESULTS}

Under macroscopic examination, the first individual showed several lobulated, well-circumscribed masses located in the left side of the trunk. The cut surface was pale and lardaceous in appearance. Histologically, the dermal growth was composed predominantly of sheets of mature unilocular adipocytes with irregular fibrovascular stroma (Fig. 2). The neoplastic proliferation was well delimited from the surrounding tissues by a pseudocapsule formed by expansive growth of the tumour on the dermis. The mass was wholly located within the dermis and clearly separated from the underlying muscular tissue by dense connective tissue.

The histopathological features were consistent with a lipoma. Additionally, a cluster of large brown to dark pigmented cells, which morphologically resembled melanomacrophage aggregates, was present in the lipoma of this specimen (Fig. 3). Unstained and HE sections examined under fluorescence microscopy exhibited positive intrinsic fluorescence associated with these cellular aggregates. Sections stained with Kinyoun's carbol fucsin method for lipofuscin revealed positive staining indicating the acid-fast nature of these aggregations. The second individual showed similar macroscopic and histopathological findings, and further development of stromal components of lipoma was also found (Fig. 4). In both individuals the overlying epidermis showed focal hyperplasia and erosion (Fig. 5).
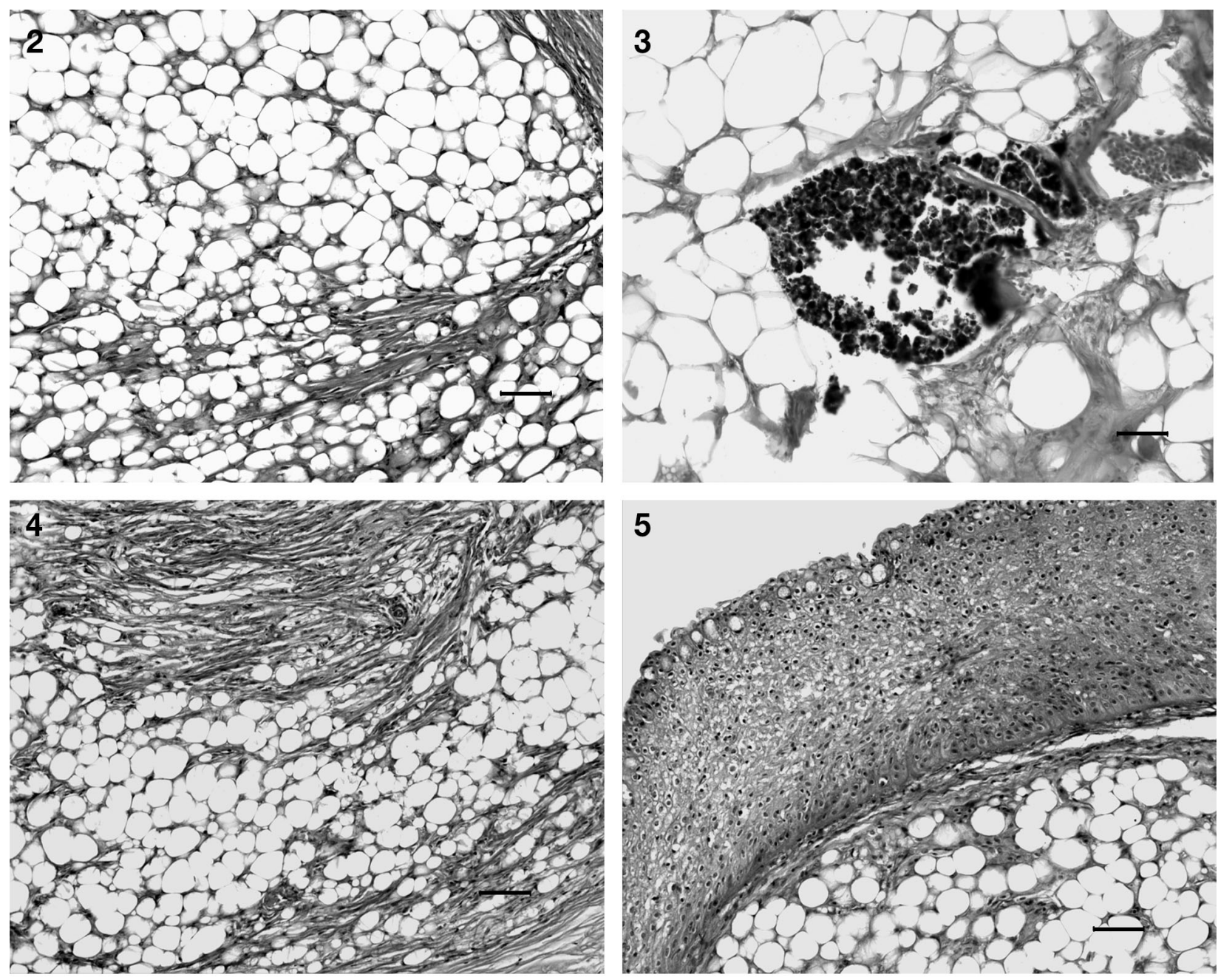

Figs. 2 to 5. Lithognathus mormyrus. Fig. 2. Sheets of mature unilocular adipocytes with irregular fibrovascular stroma. Fig. 3. Melanomacrophage aggregates in the lipoma. Fig. 4. Focal increase in stromal components of tumour. Fig. 5. Lipoma with an overlying hyperplastic epidermis. All images: H\&E stain, scale bars $=50 \mu \mathrm{m}$ 


\section{DISCUSSION}

Subcutaneous lipomas are usually well circumscribed single or multiple tumours of adipose tissue. In both the present cases histopathological observations confirmed the diagnosis of a lipoma. Histologically, a lipoma is often indistinguishable from normal adipose tissue. Lipomas are localized nodules of otherwise normal appearing fat; it is only their macroscopic appearance as a lump that has justified their traditional inclusion as neoplasms (Yager \& Scott 1985). The second individual showed a proliferation of stromal components that must not be considered as fibrolipoma as their distribution was focused.

Lipomas may occur as well-differentiated or encapsulated, dermal or hypodermal neoplasms that may result in cutaneous ulceration (Groff 2004). In the present study, erosive lesions were found next to the epidermal hyperplasia, possibly of mechanical etiology.

Autofluorescence and positive staining with Kinyoun's method were considered indicative of lipofuscin inclusions located in the cytoplasm of pigmented cells. From these observations it might be concluded that pigmented cells correspond to melanomacrophage aggregates. This cellular type is found in the stroma of various organs of fish, where they may develop many functions (Agius \& Roberts 2003). In this case the presence of these aggregations is unknown, though they

Editorial responsibility: Sven Klimpel,

Düsseldorf, Germany might be related to the occurrence of a pathological process of tumoral nature.

Acknowledgements. Thanks to Prof. J. Serrano for his valuable comments.

\section{LITERATURE CITED}

Agius C, Roberts RJ (2003) Melano-macrophage centres and their role in fish pathology. J Fish Dis 26:499-509

- Easa ME, Harshbarger JC, Hetrick FM (1989) Hypodermal lipoma in a striped (grey) mullet Mugil cephalus. Dis Aquat Org 6:157-160

Goldschmidt MH, Hendrick MJ (2002) Tumors of the skin and soft tissues. In: Meuten DJ (ed) Tumors in domestic animals. Iowa State Press, Ames, IA, p 45-117

$>$ Groff JM (2004) Neoplasia in fishes. Vet Clin North Am Exot Anim Pract 7:705-756

Johnston CJ, Deveney MR, Bayly T, Nowak BF (2008) Gross and histopathological characteristics of two lipomas and a neurofibrosarcoma detected in aquacultured southern bluefin tuna, Thunnus maccoyii (Castelnau), in South Australia. J Fish Dis 31:241-247

Marino F, Monaco S, Salvaggio A, Macrì B (2006) Lipoma in a farmed northern bluefin tuna, Thunnus thynnus. (L.). J Fish Dis 29:697-699

McCoy CP, Bowser PR, Steeby J, Bleau M, Schwedler TE (1985) Lipoma in channel catfish (Ictalurus punctatus Rafinesque). J Wildl Dis 21:74-76

Yager JA, Scott DW (1985) The skin and appendages. In: Jubb KVF, Kennedy PC, Palmer N (eds) Pathology of domestic animals, Vol 1. Academic Press, London, p $407-549$

Submitted: October 27, 2008; Accepted: March 17, 2009 Proofs received from author(s): April 22, 2009 